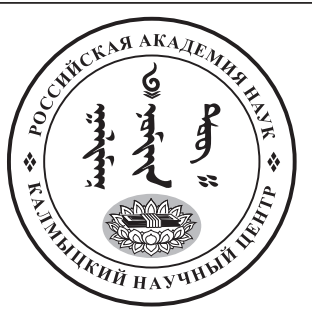

Published in the Russian Federation

Oriental Studies (Previous Name: Bulletin of the Kalmyk Institute

for Humanities of the Russian Academy of Sciences)

Has been issued as a journal since 2008

ISSN: 2619-0990; E-ISSN: 2619-1008

Vol. 13, Is. 2, pp. 252-268, 2020

DOI: $10.22162 / 2619-0990-2020-48-2-252-268$

Journal homepage: https://kigiran.elpub.ru

УДК 94 (5)

\title{
Далай-лама XIII о статусе Тибета
}

Сергей Львович Кузьмин ${ }^{1}$

${ }^{1}$ Институт востоковедения РАН

(д. 12, ул. Рождественка, 12107031 Москва, Российская Федерация)

доктор исторических наук, кандидат биологических наук, ведущий научный сотрудник iD 0000-0001-9544-1359. E-mail: ipe51@yahoo.com

Аннотация. Цель статьи - анализ взглядов Далай-ламы ХІІІ на статус Тибета в его исторической ретроспективе. Maтериальы. Изучены российские разведывательные и дипломатические документы из Архива внешней политики Российской империи (АВПРИ) с привлечением ранее опубликованных данных из архивов и мемуаров. Результаты. Согласно изученным материалам, Далай-лама XIII указывал, что отношения Далай-лам с цинскими императорами ограничивались лишь тем, что первые были «духовниками» последних, тогда как светскую власть над Тибетом Далай-лама V получил от монгольского Гуши-хана; со временем цинская власть там укреплялась и китайцы стали считать Тибет полузависимым государством, но не было ни завоевания, ни какого-либо государственного акта или документа, подтверждающего подобную зависимость, за исключением односторонних административных распоряжений китайских правителей; Тибет никогда не был под владычеством Китая; лишь позже их отношения стали переходить в вассальную зависимость Тибета; с отречением маньчжурской династии Тибет становился столь же самостоятельным, как до нее. Эти заявления Далайламы XIII согласуются с историческими фактами. Связи Далай-лам и цинскими императорами адекватно описываются отношениями «наставник - покровитель». Изученные документы показывают, что тибетско-цинские отношения трактовались обеими сторонами в ряде аспектов по-разному. До самого отречения маньчжурской династии Далай-лама не стал вассалом императора, а Тибет - частью Цинской империи. Коллапс этой империи и отречение династии дали основание Далай-ламе говорить об окончательном прекращении прежних связей Тибета с Китаем. В статье также приводятся беседы Далай-ламы XIII с российскими представителями и обсуждается церемониал его приема вдовствующей императрицей Цыси и императором Гуансюем в Пекине.

Ключевые слова: Цин, Китай, Тибет, Россия, Великобритания, независимость, сюзеренитет, государственность

Для цитирования: Кузьмин С. Л. Далай-лама XIII о статусе Тибета // Oriental Studies. 2020. Т. 13. № 2. С. 252-268. DOI: 10.22162/2619-0990-2020-48-2-252-268. 
UDC $94(5)$

\title{
The $13^{\text {th }}$ Dalai Lama on the Status of Tibet
}

Sergius L. Kuzmin ${ }^{1}$

${ }^{1}$ Institute of Oriental Studies of the RAS (12, Rozhdestvenka St., Moscow 12107031, Russian Federation) Dr. Sc. (History), Ph.D. (Biology), Leading Research Associate

(iD) 0000-0001-9544-1359. E-mail: ipe51@yahoo.com

\begin{abstract}
Goals. The work aims at analysis of the views of the $13^{\text {th }}$ Dalai Lama on the status of Tibet. Russian archival diplomatic and intelligence documents, as well as earlier published data from archives and memoirs of eyewitnesses, were used as materials. Received results reveal that the $13^{\text {th }}$ Dalai Lama had shown that connections between the Dalai Lamas and the Qing emperors were limited only by the fact that the former were 'spiritual masters' of the latter, while the $5^{\text {th }}$ Dalai Lama received secular power over Tibet from the Mongol Gushri Khan. Over time, the Qing power in Tibet was strengthened, and the Chinese began to consider Tibet a semi-dependent state. However, there were neither military conquest, nor any state act confirming such dependence, except for unilateral administrative orders from Chinese officials. Tibet was never under the rule of China, only later their relations began to transform into the vassal dependence of Tibet. With the abdication of the Manchu Dynasty, Tibet should become independent as before. These statements of the $13^{\text {th }}$ Dalai Lama correspond to historical facts. Connections between the Dalai Lamas and the Qing emperors may be sufficiently described by the 'priest-patron' principle. Documents reveal that the TibetanQing relations were treated in many aspects differently by both sides. Until the end of the Manchu Dynasty, the Dalai Lama never became a vassal to the Emperor, and Tibet was not a part of the Qing Empire. The collapse of this empire and the abdication of this dynasty gave the Dalai Lama new reason to declare final termination of the former connections between Tibet and China. The article quotes the Dalai Lama's talks with Russian officials. Elaboration of ceremony of his reception by the Dowager Empress Cixi and Guangxu Emperor in Beijing is discussed.
\end{abstract}

Keywords: Qing, China, Tibet, Russia, Great Britain, suzerainty, independence, statehood

For citation: Kuzmin S. L. The $13^{\text {th }}$ Dalai Lama on the Status of Tibet. Oriental Studies. 2020; Vol. 13(2): 252-268 (In Russ.). DOI: 10.22162/2619-0990-2020-48-2-252-268

\section{है}

\section{Введение}

Государственность Тибета составляет предмет дискуссий. Основных точек зрения три: 1) Тибет является неотъемлемой частью Китая с ХІІІ в. - со времени монгольской династии Юань; 2) Тибет был частью цинского Китая, в первой половине XX в. de facto независимым государством, а затем легитимно включен в состав КНР; 3) Тибет никогда не был частью Китая, и его включение в состав КНР нелегитимно. Обычно такие дискуссии касаются статуса Тибета со времен империй или «династий» Юань и Цин до середины XX в. Важные данные на эту тему содержатся в ряде архивных и дру- гих источников, прежде всего тибетских, маньчжурских и китайских. Большое значение имеют также дипломатические, разведывательные и другие сведения от представителей других стран, контактировавших с Тибетом. Следует привести краткий обзор этих данных.

«Китайские династии» Юань и Цин в действительности были монгольским и маньчжурским государствами, в которые покоренный Китай входил как составная часть (подробнее см.: [Дмитриев, Кузьмин 2012; Дмитриев, Кузьмин 2014]). Монгольские юаньские императоры (XIII-XIV вв.) находились в отношениях «наставник - по- 
кровитель» с главами школы Сакья тибетского буддизма. Эти отношения, не имеющие аналогов в праве нового и новейшего времени, стали приоритетом в отношениях Тибета с монгольскими императорами (подробнее см.: [Кузьмин 2010]).

У следующей империи со столицей в Пекине - китайской империи Мин - отношения с Тибетом были слабыми и спорадическими. Обсуждать подчинение в тот период не приходится. Правившие затем маньчжурские императоры государства Цин (1644-1912) установили тесные отношения с Тибетом. Именно к этому периоду относятся главные аргументы за то, что Тибет при Цинской династии был частью Китая или его вассалом.

Отношения цинских властей с Тибетом регулировались «Лифаньюань цзэли» ('Установления Палаты по управлению внешними регионами'). Тибет в этом документе рассматривался как одна из областей вне Китая, и его касалось отдельное законодательство. Это законодательство было коротким и регулировало в основном привоз «дани» императору, «утверждение» перевоплощенных лам, сбор налогов, поступавших в казну Тибета и т. д. [Уложение 2, 1828, 2: 191-277]. Из него нельзя сделать выводов о том, был ли Тибет частью империи, колонией, зависимым государством или чем-то еще.

Косвенно это подтверждает статья в официальной пекинской газете «Диго шибао» в 1910 г. (1-го числа 3 луны 2 года Сюаньтун), где, в частности, сказано: «Наша династия с самого ее расцвета и до сего времени по отношению к малым государствам или своим колониям держалась особой политики. Она вменяла им в обязанность принесение ко двору дани и нисколько не вмешивалась во внутренние дела этих государств и колоний. Поэтому инородцы по-прежнему пользовались свободой и самоуправлением и получали к тому же гуманное покровительство и поддержку нашей династии. Такова была политика привлечения, применяемая по отношению к островам Лю-цю, Корее. Монголия же связывалась с Китаем посредством политических браков монгольских князей с китайскими принцессами. Тибет был связан с Китаем посредством религии. Если бы европейцы и американцы не появились, то, конечно, такая политика могла бы продолжаться, и Китай наслаждался бы покоем. К тому же наша династия пользовалась некоторой административной властью в Тибете, что имело сходство с колониями иностранцев, имевшими быть населенными из метрополии. Перемена политики была легко бы осуществимой, но без труда и без денежных затрат невозможно пользоваться было бы долгим спокойствием. Это тем более, что с того времени, как Россия и Англия обратили внимание на Тибет, который мог стать второй Маньчжурией, политика привлечения уже перестала быть удобной. Если она была применима в прежнее время, то ныне условия несколько иные» (рус. перев.: [АВПРИ. Ф. МП. ОП. 761. Д. 411. Л. 26-29]).

Императорские указы и печати, дававшиеся Далай-ламе в разных перевоплощениях, согласуются с синоцентристской мироустроительной моделью, где любые подарки императору - это дань, а выдаваемые им печати и дипломы - признаки его власти над теми, кому они выдаются, независимо от того, как это расценивали сами принимавшие. Вот, например, содержание императорского указа Далай-ламе XI. Далай-лама есть глава учения Цонкапы ${ }^{1}$. Император награждает его нефритовой печатью, которой Далай-лама должен пользоваться постоянно и относиться к ней с соответствующим уважением. Ее надо употреблять лишь в тех случаях, когда возникают дела государственной важности или для особых представлений к богдохану르, в прочих случаях - употреблять старую печать. «Настоящую нашу императорскую награду должны принять с почтением и затем всегда быть преданным исполнителем нашей воли и распространять святое учение желтой веры ради процветания среди народов спокойствия и благоденствия» [АВПРИ. Ф. МП. ОП. 761. Д. 413. Л. 262-263]. Перевод с монгольского языка императорского пожалования Далай-ламе XI золотого диплома: «Мы признали Вас достойным награды титулом „Священный Очир Дара Далай-лама“ с предоставлением Вам права неограниченного (верховного?) повелителя благотворных западных стран и главы Буддийской религии на всей земле» [АВПРИ. Ф. МП. Оп. 761. Д. 413. Л. 264об.].

\footnotetext{
${ }^{1}$ Т. е. тибетского буддизма школы Гелуг.
}

2 Цинскому императору. 
Это - стиль повелителя к подчиненному. Он аналогичен тому, что использовали цинские императоры в период следования традиционной мироустроительной модели в отношении европейских королей и посольств (см.: [Backhouse, Bland 1914: 325-334; Fairbank, Teng 1941: 135-246]). Однако рескрипты императора о Далай-ламе для своих сановников и для тибетцев могли быть разными: для первых император представал сыном Неба и повелителем Поднебесной, для вторых - покровителем буддизма [Беспрозванных 2001: 167].

Цинский император Шуньчжи послал Далай-ламе V после встречи с ним в Пекине печать и золотой диплом, которые тот принял. Считая свои отношения с ним продолжением отношений высших лам Сакья с юаньскими императорами, Далай-лама $\mathrm{V}$ указывал, что титул получил по велению императора. Однако это подразумевало не уступку императору права вмешиваться в тибетские дела, а было простым признанием последнего центром политического притяжения во Внутренней Азии [Schwieger 2015: 63-64].

Аналогичны формулировки и в документах последующих воплощений Далай-ламы, в том числе Далай-ламы XIII до 1909 г. [Schwieger 2015: 206; Ishihama et al. 2019: 83-106]. Так, в эдикте от 20 января 1899 г. сказано: «Речь того, кто по велению императора назван самым могущественным повелителем в высшей степени добродетельной западной сферы, держателем всего учения Будды на Земле, всезнающим Ваджрадхарой Далай-ламой» [Schwieger 2015: 206]. Та же формулировка содержится и в эдикте, изданном им в январе 1902 г., где красными чернилами написаны апелляции к императору и Далай-ламе, а также слова о буддийском учении. На документе есть два оттиска печати Далай-ламы [Schwieger 2015: 206].

Приведенные материалы не позволяют определить реальный статус Тибета. Но в рамках синоцентристского исторического мифа они могут трактоваться как сюзеренитет или суверенитет Китая над Тибетом. Следуя этому мифу, китайцы считали Тибет подчиненным им. Так, в пекинских газетах писали: «Что же такое представляет собой Тибет? - Это нам принадлежащая страна. - Что такое Далай-лама? - Это китайский сановник, управляющий Тибетом. Таким образом, Тибет не есть самостоятельное государство, и Далай-лама не обладает суверенной властью» (рус. перев. из «Го бао», 06-07.03.1909: [АВПРИ. Ф. МП. Оп. 761. Д. 410. Л. 338-338об.]); «Согласно основному положению, Далай-лама заведует распространением желтой веры и [является] ее главным наставником, а политика, военное дело и финансы Тибета находятся целиком в руках китайского резидента. Такое положение заставляет уподобить отношение Тибета к Китаю таковому Индии к Великобритании» (рус. перев. из «Шуньтянь шибао», 14.02.1910: [АВПРИ. Ф. МП. Оп. 761. Д. 411. Л. 37]).

Выводы иностранцев о статусе Тибета в XIX - начале XX в. более разнообразны. Приведу некоторые, наиболее известные и характерные: Цинская династия, возможно, включала в себя Тибет; император - друг и покровитель Далай-ламы; Тибет находится в зависимости от Китая; политическое верховенство Китая в Тибете; китайский сюзеренитет над ним; император - сюзерен Тибета; Тибет - китайский протекторат; сюзеренитет Китая над Тибетом - конституционная фикция (источники см.: [Кузьмин 2014]).

Примечательны последовательные изменения формулировок в книгах Ч. А. Белла - британского политического офицера в Бутане, Сиккиме и Тибете, знакомого с Далай-ламой XIII: после 1912 г. Тибет стал de facto независимым государством [Bell 1924: 217]; в Тибете есть китайское влияние [Bell 1928: 17]; китайский сюзеренитет, если имелся, то был чисто номинальным; во время своего правления Далай-лама XIII упразднил китайское господство на большой части Тибета, и эта часть стала полностью независимым царством, оставаясь таковым последние 20 лет его жизни [Bell 1946: 60, 391]

В структурах российского МИД Тибет в то время обычно считали вассалом Китая, обозначали как «страну» или «государство» [например, АВПРИ. Ф. КС. Оп. 491. Д. 78. Л. 37; АВПРИ. Ф. КС. Оп. 491. Д. 85. Л. 119об.]. Однако мнения там не были одинаковыми. Так, в отчете совещания в Петергофе по тибетским делам 11 июня 
1906 г. ${ }^{3}$ говорилось, что «Тибет является составной частью Китая, который осуществляет свое верховенство через посредство двух амбаней, располагающих известным количеством войск, впрочем, весьма ограниченным» [АВПРИ. Ф. КС. Оп. 491. Д. 85. Л. 123-126]. Управляющий российским генконсульством в Бомбее С. В. Чиркин 1 апреля 1909 г. сообщал, что «Китаю удалось восстановить свой сюзеренитет над Тибетом» [АВПРИ. Ф. КС. Оп. 491. Д. 1458. Л. 14] - следовательно, ранее таковой был утрачен. Позже он сообщал, что раньше Тибет был «фактически независимой» страной [АВПРИ. Ф. КС. Оп. 491. Д. 1458. Л. 24об.].

В аналитической статье «В ожидании Далай-ламы» в «Санкт-Петербургских ведомостях» за 7 апреля 1910 г. говорилось: «Когда 5-й Далай-лама во второй раз приехал в гости к богдыхану, император принял его торжественно, как царственного главу независимого Тибета <...> Китайцы $<\ldots>$ при 7-м же Далай-ламе учредили амбаньство в Лхасе, передав власть суверенного правителя - тибетского хана самому Далай-ламе $<\ldots>$ Китай стал стремиться к верховной власти над Тибетом <..> То, что Китай признавал Тибет государством, можно усмотреть из тех договоров о вечном мире и согласии, которые в разные времена Китаем были заключены с Тибетом < ..> В сущности, царство лам до последнего времени являлось государством, находившимся лишь под протекторатом Китая» [АВПРИ. Ф. КС. Оп. 491. Д. 1458. Л. 96].

Такая вариация в оценках требует выяснения статуса Тибета на основе критериев, универсальных для разных стран. В предыдущей работе было показано, что типологическими признаками вассалитета, общими для Европы и Азии, были следующие: подчинение нижестоящих представителей знати (вассалов) вышестоящим (сеньорам, монархам) с клятвой верности, обязательством или письменным соглашением; служба (особенно военная, но также административная, и/или помощь, выплата дани, нало-

${ }^{3}$ Присутствовали, кроме сотрудников МИД, Я. П. Шишмарев, А. М. Позднеев, генерал Н. М. Чичагов, генерал И. П. Надиров, князь Э. Э. Ухтомский, С. Ф. Ольденбург, В. В. Владимиров (действительный статский советник, директор департамента духовных дел иностранных исповеданий), П. К. Козлов. гов и т. п.) вассалов сеньорам; пожалование вассалам сеньорами земли, другого имущества или прав в обмен на верность и службу; одинаковое понимание обеими сторонами данных отношений. Те формы отношений, которые не включают какой-либо из этих признаков, нельзя считать вассалитетом; не являлись им и ситуации, когда обе стороны трактовали свои отношения по-разному [Кузьмин 2019: 39-54]. Далай-ламы и цинские императоры одинаково трактовали лишь свои отношения «наставник - покровитель» [Кузьмин 2012: 261-273].

Для решения поставленной проблемы приоритетное значение представляет мнение самих Далай-лам, до середины XX в. являвшихся монархами Тибета. В наиболее обобщенной форме оно отражено во взглядах Далай-ламы XIII Тубтена Гьяцо (18761933), жившего в период коллапса империи Цин и провозгласившего в начале XX в. независимость Тибета. Его документальное наследие на эту тему мало изучено. Главные источники на эту тему - сохранившиеся высказывания, письма и указы Далай-ламы, данные о его взаимодействии с цинским руководством и т. д., воспоминания разных лиц об общении с ним, цинские документы. В сумбуме (собрании сочинений) Далай-ламы XIII (хранится в Библиотеке тибетских трудов и архивов (LTWA) в Дхарамсале, Индия) не найдено точных данных о статусе Тибета. Сведения на эту тему Далай-лама XIII приводил российским дипломатам в период своего пребывания в Монголии в 1904-1906 гг., когда он тщетно пытался получить признание независимости Тибета [АВПРИ. Ф. МП. Оп. 761. Д. 409. Л. 192об.] и помощь России, а также в последующих документах. Попробуем сопоставить его взгляды с приведенными выше данными о статусе Тибета.

\section{Основная часть}

В инструкции своему уполномоченному в России и Монголии А. Доржиеву в 1905 г. Далай-лама писал, что обратился к российскому царю, чтобы «просить Его разобрать спор великобританского и тибетского правительств, признать всегда существовавшую независимость Тибета» [АВПРИ. Ф. МП. Оп. 761. Д. 413. Л. 223-223об.].

Российский консул в Урге В. Ф. Люба сообщал 6 августа 1905 г.: «Возбужденный воспоминаниями о китайских происках и 
коварстве Англии, с которыми ему пришлось бороться в течение многих лет, Далай-лама горячо и с убеждением отстаивал свой взгляд на внешнюю, чисто номинальную зависимость своей страны от Китая. С горечью говорил он, что Китай более чем пассивно относился к нарушению англичанами неприкосновенности тибетской территории, что правительство богдохана осталось совершенно безучастно к его судьбе после удаления его из Тибета ${ }^{4}$; что и в настоящее время китайцы не позаботились даже поставить его в известность относительно заключения ими с Англией нового договора, решающего судьбу Тибета $<\ldots>$ Ему известно, что маньчжурский амбань в Лхасе настаивает перед своим правительством на лишении его духовной и светский власти и о передаче прав, принадлежащих ему, как Далай-ламе, Панчен-Богдо; что в Пекине распространяются усиленные слухи об открытом переходе его на сторону России <...> Далай-лама осведомлен также, что богдохан не дал пока еще своей санкции на настойчивые домогательства своего представителя в Тибете. На самом деле богдохан, по главному убеждению первосвященника, не имеет права лишить его ни светской, ни духовной власти.

По закону церкви Далай-лама является духовником богдохана, получает от него духовную печать; этим и ограничиваются их взаимные отношения, и лишь насилием богдохан мог бы подчинить своей власти первосвященника. Светскую же власть Далай-лама принял преемственно вместе с печатью правителя Тибета от Ушири-ха$\mathrm{Ha}^{5}$, царившего в Монголии при китайском императоре Кан-си. В те времена — рассказывал, переносясь в историческую эпоху своей страны Далай-лама - Тибет представлял из себя 13 мелких, вполне независимых друг от друга и постоянно враждовавших между собой княжеств. Ушири-хан покорил их и передал светскую власть над ними пятому Далай-ламе. Объединенный Тибет, имея своего самостоятельного правителя, являлся при Кан-си не вассалом, а

4 Имеется в виду позиция правительства цинского императора в период вторжения англичан в Тибет в 1904 г.

5 Турубайху Гуши-хан (1582-1654) - правитель ойратов-хошутов, передавший власть над Тибетом Далай-ламе V. вполне самостоятельным союзником Китая, и лишь с течением времени китайцы заняли более прочное положение в Тибете и стали считать его полузависимым государством. Между тем, ни завоевания силой оружия, ни какого-либо государственного акта или документа, подтверждающего подобную зависимость Тибета от Китая, в истории обеих стран не было, если не считать документами односторонние распоряжения китайских правителей административного характера.

Далай-лама, по его словам, ставил эти факты на вид богдоханскому правительству, и маньчжурские чиновники не могли ничего возразить против этого. И в настоящее время Далай-лама считает, что взаимные отношения стран и обстоятельства не настолько изменились в пользу Китая, чтобы он мог присвоить себе права, принадлежащие исключительно ему, Далай-ламе, распоряжаться судьбой Тибета. Основываясь на этом положении, Первосвященник не признает этот договор ${ }^{6}$, как не признал в свое время конвенцию девятидесятого года - имеющим для него, как правителя Тибета, какую-либо юридическую силу. $<\ldots>$ Наиболее чувствительным местом для Далай-ламы оказалась статья договора, устанавливающая оккупацию английскими войсками - хотя и временную - тибетской территории» [АВПРИ. Ф. КС. ОП. 491. Д. 78. Л. 172-174 (машинописная копия); АВПРИ. Ф. МП. Оп. 761. Д. 413. Л. 224-226 (машинописный 1-й экз.)].

По свидетельству кяхтинского пограничного комиссара А. Д. Хитрово, Далай-лама документально и исторически доказывал российскому консульству права своей светской власти над Тибетом, указывал, что Тибет никогда не был под владычеством Китая, а с упразднением маньчжурской династии он должен стать столь же самостоятельным, как до нее (текст: [Белов 1996: 136-141]). В особом приложении при письме Николаю II Далай-лама XIII сообщал, что Тибет с самого начала был самостоятельным независимым государством; при цинском императоре Шуньчжи между ними установились отношения государственного духовника и императора, а также

${ }^{6}$ Ф. Янгхасбенда и чиновников Лхасы, подписавших соглашение после вторжения англичан в Лхасу (когда Далай-лама бежал в Монголию). 
на будущее - неизменная дружба и взаимная солидарность в действиях. «С этого времени отношения Тибета к Китаю стали отличаться особенной дружественностью и преданностью. Такое взаимоотношение в последующие времена постепенно переходит в вассальную зависимость Тибета от Китая» (цит. по: [Россия и Тибет 2005: 159-160]).

Изучение переписки Далай-ламы XIII c американским посланником в Пекине В. В. Рокхиллом и японским монахом Э. Терамото на закате империи Цин показало, что Далай-лама XIII описывал исторические отношения Тибета с этой империей термином рангизен (независимость), а не иерархическим подчинением цинскому императору. Далай-лама говорил о необходимости восстановления этого рангизен, который стараются односторонне отменить цинские чиновники, а также восстановления отношений «наставник - покровитель» с цинским императором. В письмах королю Георгу V и британскому премьер-министру Далай-лама указывал, что отношения Тибета и Китая - это отношения «священник - ученик» и Тибет никогда не был «подданным власти Китая» [Ishihama et al. 2019: 55-57, 226-231]. Эти заявления согласуются с приведенными выше его заявлениями российским представителям.

В период своего заката империя Цин переходила от даннической к договорной системе международных отношений. Там начинали внедряться западные термины «сюзеренитет», «суверенитет» и «вассалитет». После вторжения англичан в Лхасу в 1904 г. Британия не только давила на империю Цин, чтобы она приняла сюзеренитет как надлежащее выражение своих отношений с Тибетом, но и пыталась манипулировать тем, какие языковые коды должны использоваться в китайском языке для формулирования этой конструкции. Вместо обсуждения, осуществляет ли она сюзеренитет или суверенитет, разговор переходил в дебаты, является ли Китай «верхней» страной Тибета, или «страной-хозяином». Один из высших сановников - князь Цин на вопрос британского посланника в Пекине Э. М. Сатоу об отношениях Тибета к Китаю отвечал, что «нет точного слова для выражения этого». Но в дальнейших переговорах с Великобританией Пекин отказывался принимать термин «сюзеренитет» в отношении Тибета, так как считал, что лучше подходит термин «суверенитет». Поэтому в «Конвенции между Великобританией и Китаем о Тибете» от 27 апреля 1906 г. термины «сюзеренитет» и «суверенитет» не использованы [Cheney 2017: 11-3].

31 августа 1907 г. в Петербурге была подписана «Конвенция между Россией и Великобританией по делам Персии, Афганистана и Тибета». По ней обе державы обязались не вмешиваться в дела Тибета, но при этом признали «сюзеренные права Китая над Тибетом» и обязались «сноситься с Тибетом только через посредство китайского правительства» [Россия и Тибет 2005: 114].

Эта схема работала и далее. В Особом журнале Совета министров России от 21 мая 1911 г. Далай-лама именуется «вассалом Китая» [АВПРИ. Ф. КС. Оп. 491. Д. 1458. Л. 191об.], в записке А. Доржиева в марте 1912 г. Тибет именуется «автономной политической единицей Китая» [АВПРИ. Ф. КС. Оп. 491. Д. 1458. Л. 314].

Однако между Тибетом и империей Цин не было документов о таком сюзеренитете. Следовательно, он был зафиксирован «через голову» их другими странами. Сохранился черновой русский перевод послания Далай-ламы к тибетскому народу (оригинал неизвестен), написанного, очевидно, после подписания указанной конвенции. В нем Далай-лама заявлял, что он глава буддизма и глава Тибета, «Мировое положение Тибета пред Великими Державами на будущее время установились отныне и как прежде признанием над ним сюзеренного права Богдо-хана. Верховное управление внутренними нашими делами принадлежит ведению правительствующего нашего собрания „Дэба-Шунга“" во главе с Далай-ламой» [Сабрукова 2015: 134-139]. Далее описаны правительственные функции Дэвашунга, причем функции цинского императора сводятся к назначению регента до совершеннолетия Далай-ламы и утверждению калонов (министров) с одобрения Далай-ламы [Сабрукова 2015: 134-139]. Таким образом, прямо не отрицая цинский сюзеренитет, Далай-лама ограничил его формулой международных отношений и участием в администрировании. Показано, что тибетские термины, использовавшиеся тогда для навязанного 
Тибету «сюзеренитета» — «Тибет (является) внешней под китайской территорией» и т. п., - отражают тот факт, что было трудно перевести с английского политический термин «сюзеренитет» на традиционный тибетский [Ishihama et al. 2019: 139].

В координации с Пекином и Лондоном российским дипломатам удалось убедить Далай-ламу XIII вернуться из Монголии в Тибет через Пекин. В цинской тронной переписке его называли «подведомственным нам Далай-ламой» (например: [АВПРИ. Ф. КС. Оп. 491. Д. 1457. Л. 47]). В Пекине ему должны были «вернуть» титул, которого его «лишили» императорским указом за выезд из Тибета в Монголию.

Помимо принятия дипломов и печатей, важным символом подчинения цинским императорам была церемония 3-кратного коленопреклонения и 9-кратного челобитья - коутоу. В синоцентристской модели ее исполнение однозначно трактовалось как подчинение императору. Не всем иностранцам удавалось избежать этого (например, не удалось ряду голландских представителей) - что не означало принятия цинского подданства. И вот теперь, при разработке церемониала приема Далай-ламы императором (а фактически правившей вместо него Цыси), коленопреклонению придали большое значение. Выработка этого церемониала примечательна.

Цинские сановники Богун и Дашоу написали Далай-ламе, что «было повергнуто на Высочайшее воззрение», чтобы Далай-лама поклонился перед Небесным престолом, после чего при принятии подарков Их Величеств «выполнил требуемую законом церемонию», о чем последовал Высочайший указ [АВПРИ. Ф. КС. Оп. 491. Д. 1457. Л. 63-66об.].

В июле 1908 г. в Пекине губернатор провинции Шаньси сообщил краткое описание церемонии приема Далай-ламы и «объявил во всеобщее сведение указ императоpa, коим Далай-лама призывается в столицу для аудиенции» [АВПРИ. Ф. МП. Оп. 761. Д. 410. Л. 47-49 об.]. Описывались приготовления к этому, к встрече и его сопровождению чиновниками, охраной и ламами. Лифаньюань испросил указ о назначении дня аудиенции, причем предварительно в Желтом храме следовало произвести репетицию ее церемониала. В день аудиенции
Далай-лама, войдя в зал, должен был осведомиться у императора, который при этом встает, о его здоровье и поблагодарить его за милости. Император, приняв приветствие, поднимается на трон и милостиво предлагает Далай-ламе сесть на низкое сиденье, которое будет поставлено у трона, и выпить чаю. Затем Далай-лама сделает доклад о положении дел в Тибете. Затем следуют подарки императрицы и императора. Потом - проводы [АВПРИ. Ф. МП. Оп. 761. Д. 410. Л. 47-49 об.].

Но затем программу изменили. Аудиенцию назначили в зале Жэнь-хэ. «При входе Далай-ламы император встает. Далай-лама приветствует поясным поклоном. Приносит благодарность за милостивые награждения земным поклоном. Император садится и слева предлагает место Далай-ламе» [АВПРИ. Ф. МП. Оп. 761. Д. 410. Л. 86].

Далай-лама подносит хадак ${ }^{7}$ через генерал-адъютанта. «Император принимает хадак стоя. Таким же порядком передается ответный хадак. Император садится и предлагает место Далай-ламе» [АВПРИ. Ф. МП. Оп. 761. Д. 410. Л. 86].

16 сентября 1908 г. последовал императорский указ, где было сказано: «Повелеваем Далай-ламе прибыть 23-го сего сентября в тронную залу /Жэнь-шоу-дянь/ для аудиенции. Быть по сему» [АВПРИ. Ф. МП. Оп. 761. Д. 410. Л. 88].

Российский дипломат И. Я. Коростовец, служивший тогда в Пекине, сообщал в МИД 22 сентября 1908 г.: «Я советовал посланцу Далай-ламы вообще избегать протестов против церемониала аудиенции у Богдохана, несмотря на то, что таковой церемониал значительно упрощен по сравнению с бывшими прецедентами. Появился указ, отменяющий аудиенцию 23 сентября, о новом сроке будет объявлено дополнительно <...> По последним сведениям, Далай-лама будет принят прежде вдовствующей императрицей по церемониалу, установленному для вассальных правителей» [АВПРИ. Ф. МП. Оп. 761. Д. 410. Л. 116-119]. После этого «Далай-лама сообщил, что по предположенному церемониалу Первосвященник при представлении вдовствующей императрице должен совершить коленопреклонение (котоу), что Далай-лама, находя это требова-

\footnotetext{
${ }^{7}$ Тиб. ката - церемониальный шарф.
} 
ние унизительным и неподобающим сану, просит моего совета и воздействия на китайцев...» [АВПРИ. Ф. МП. ОП. 761. Д. 410. Л. 125-126]. Он получил ответ, что китайцы, предъявляя такое требование, смотрят на Далай-ламу не как на духовного главу буддизма, «а как на вассального правителя Тибета, обязанного совершать обряд котоу не только перед особой монарха, но даже перед посылаемыми им дарами или таблицей с его именем...» [АВПРИ. Ф. МП. ОП. 761. Д. 410. Л. 125-126]. Что касается просьбы, то было повторено, что эти требования внутреннее дело Китая, этим китайцы хотят подтвердить вассальную зависимость Далай-ламы «и, умалив его значение, ослабить возможность противодействия при осуществлении своих планов относительно Тибета» [АВПРИ. Ф. МП. Оп. 761. Д. 410. Л. 125-126]. Упоминавшийся выше Э. Терамото тоже убеждал Далай-ламу, посетившего японское посольство, не возражать «ради сохранения единства буддийского мира» [Ishihama et al. 2019: 89-90].

Церемониал представления Далай-ламы вдовствующей императрице и императору продолжал разрабатываться. Когда император воссядет на трон, в зал вводят Далай-ламу, «Далай-лама сбоку от трона становится на колени. Почтительно, стоя на коленях, передает статую Будды и хадак, и флигель-адъютант их подносит императору. Далай-лама коленопреклоненно вопрошает о здоровье вдовствующей императрицы и делает земной поклон, благодаря за оказанные милости. Затем Далай-лама коленопреклоненно выслушивает вопросы и речь вдовствующей императрицы и дает ответы» [АВПРИ. Ф. МП. Оп. 761. Д. 410. Л. 125-126].

По окончании церемонии Далай-ламу и прочих выводят, они ждут, когда на трон воссядет император. Затем Далай-лама входит, встает на колени, дает статую Будды и хадак, вопрошает коленопреклоненным о здоровье императора и делает земной поклон, благодаря за оказанные милости, коленопреклоненным выслушивает слова императора и дает ответ [АВПРИ. Ф. МП. Оп. 761. Д. 410. Л. 125-126]. Далай-лама был сильно недоволен таким церемониалом. Слухи об этом даже попали в китайскую прессу («Шуньтянь шибао», 25.09.1908: [АВПРИ. Ф. МП. Оп. 761. Д. 410. Л. 131]).
Сановники Дашоу и Чжан Иньтан посетили Далай-ламу и спросили, понял ли он предложения об аудиенции. Он ответил, что приблизительно. Дашоу спросил, имеет ли Далай-лама что сказать на первой аудиенции. Он ответил, что ничего не имеет сказать. Чжан Иньтан с трудом сдерживал негодование. Затем обсуждали, как положено сидеть амбаню относительно Далай-ламы. Произошла ссора, и Чжан Иньтан уехал, не попрощавшись, но Дашоу попрощался [АВПРИ. Ф. МП. Оп. 761. Д. 410. Л. 144-145об.].

Аудиенция состоялась в летнем дворце 1 октября 1908 г. (очевидно, 14 октября по новому стилю). Китайская газета «Шунтянь шибао» 03.10.1908 сообщала, что Далай-лама совершил коутоу перед императором, затем подал ему желтый хадак, который император принял стоя. Потом последний разрешил Далай-ламе сесть [АВПРИ. Ф. МП. Оп. 761. Д. 410. Л. 147-148].

Это лишь частично согласуется с телеграммой из миссии в Пекине в МИД России: 1 октября Далай-лама представлялся императору и императрице в летнем зале Жэньшоу-дянь, где И. Я. Коростовец вручал свои верительные грамоты. «Первосвященник сделал земной поклон перед императрицею и кланялся в пояс Богдохану. Далай-лама был засим посажен на низком сидении рядом с императором, удостоившись краткой беседы» [АВПРИ. Ф. МП. ОП. 761. Д. 410. Л. 153-153об.]. Далай-лама под тесным надзором китайских чиновников был лишен возможности проявлять какую-либо инициативу [АВПРИ. Ф. МП. Оп. 761. Д. 410. Л. 153-153об.].

5 октября 1908 г. последовали императорские указы, где, в частности, говорилось: «Повелеваем Далай-ламе в день пиршества опускаться на колени в тот момент, когда Их Императорские Величества будут входить в зал или удаляться из оного. Быть по сему» [АВПРИ. Ф. МП. Оп. 761. Д. 410. Л. 158-158об.]. Прошло правительственное обсуждение преобразования Тибета, было решено, что немедленное преобразование Тибета в провинцию не вполне удобно, лучше отложить вопрос до возвращения туда Далай-ламы: после того, как такое преобразование в провинцию произойдет в Монголии, можно преобразовать в провинцию и Тибет («Шуньтянь шибао», 08.10.1908: 
[АВПРИ. Ф. МП. Оп. 761. Д. 410. Л. 161]). Затем последовал императорский указ от 11 октября 1908 г.: «Повелеваем Далай-ламе явиться 20-го сего октября в залу Цинчжэн-дянь для представления дани. Быть по сему» [АВПРИ. Ф. МП. Оп. 761. Д. 410. Л. 173].

По сообщениям пекинской прессы, 17 октября был дан торжественный обед в честь Далай-ламы. «Когда император милостиво удостоил переданной через монгольских князей и бэйлэ чарки вина, Далай-лама почтительно принял, встав на колени, и кое-как по-китайски произнес благодарность императору» («Шунтянь шибао», 08.10.1908: [АВПРИ. Ф. МП. Оп. 761. Д. 410. Л. 191]). Во время торжественного обеда Далай-лама был подведен чиновниками к императору, перед которым он сделал 3 коленопреклонения по 3 земных поклона каждое («Бэйцзин шибао», 20.10.1908: [АВПРИ. Ф. МП. Оп. 761. Д. 410. Л. 199]) т. е. коутоу. Наконец, появился императорский указ. В исследованиях упоминается лишь содержание этого указа. Приведем его перевод полностью:

«Указ Богдохана от 21 октября 1908 г. Я почтительно получил от вдовствующей императрицы Цы-си указ следующего содержания. Далай-лама, прибыв в прошлой луне в столицу, был принят нами на аудиенции сегодня, вместе со своими учениками он вознес моление о счастии императорской фамилии и выразил при этом свои задушевные чувства, за что поистине заслуживает поощрения. Поэтому мы признаем справедливым пожаловать ему в виде особой милости новый почетный титул, дабы проявить этим наше особенное к нему благоволение.

На основании прежних установлений Далай-ламе уже был пожалован титул „Западного, Небесного, Великого, Милостивого и Самодовлеющего Будды“. Ныне в виде особой милости мы жалуем ему титул „Искреннего, Покорного, Содействующего распространению просвещения, Западного, Небесного, Великого, Милостивого и Самодовлеющего Будды“. Что же касается церемониала пожалования ему нового титула, то таковой имеет быть в самом непродолжительном времени выработан министерствами церемоний и колоний, которые должны войти по сему предмету с докладом. Кроме того, на прокормление жалуется ему еже- годно по 10000 лан, каковая сумма и подлежит выдаче по четвертям года из казначейства Сычуаньской провинции. После того, как состоится церемония пожалования Далай-ламе нового титула, он должен будет немедленно отправиться обратно в Тибет, причем власти тех местностей, через которые он будет проезжать, обязаны командировать чиновников для сопровождения его от одной станции до другой и для оказания всяческого содействия.

По прибытии в Тибет Далай-лама должен будет неукоснительно соблюдать законы и постановления своего суверенного государства и содействовать распространению доверия к китайскому правительству, а вместе с тем просвещать тибетское население указывать ему на необходимость почтительного соблюдения постановлений, постепенно содействуя таким образом их нравственному усовершенствованию. О всех делах он по прежнему должен докладывать китайскому резиденту в Тибете, который, со своей стороны, своевременно представляет о них доклад трону, и почтительно ожидать императорского решения. При таких условиях окраинам империи на вечное время будет обеспечено вечное спокойствие, а между духовными и светскими уничтожено будет всякое различие, что вполне соответствует высоким намерениям правительства содействовать сохранению поддержания Желтой веры, успокоению и умиротворению границ империи. Одновременно повелеваем министерству колоний сообщить содержание настоящего указа Далай-ламе для почтительного руководства» [АВПРИ. Ф. МП. Оп. 761. Д. 410. Л. 4-4об.].

Фраза о том, что сам император «почтительно получил от вдовствующей императрицы Цы-си указ» примечательна. Она свидетельствует о нарушении основ цинской мироустроительной концепции: глава государства - император - не сам издает указы, а «почтительно получает» их от вдовствующей императрицы. Именно она по факту и правила страной. Соответственно в придворных записях было зафиксировано: в день рождения Цыси перед ней весь ее двор, Далай-лама и император совершили коутоу [Smith 1996: 166].

Затем стал известен «Проект всеподданнейшего доклада Далай-ламы» такого содержания. Маньчжуры, монголы, ки- 
тайцы и тибетцы одинаково чтут буддизм. Духовенство всегда было осыпано милостями вдовствующей императрицы и императора «и потому обращается ныне с покорнейшей просьбою всемилостивейше разрешить им спокойно вести прежний образ жизни» [АВПРИ. Ф. МП. Оп. 761. Д. 410. Л. 5-5об.]. Впоследствии и сам Далай-лама мог бы входить с всеподданнейшим докладом по всем важным вопросам или совместно с китайским резидентом в Лхасе. Подчеркивалось, что он просит «новой милости, именно, предоставить мне право входить со всеподданнейшим докладом, в каковом ходатайстве поистине нет ни малейшего уклонения от старого миропорядка» [АВПРИ. Ф. МП. Оп. 761. Д. 410. Л. 5-5об.].

23 октября 1908 г. И. Я. Коростовец сообщал из Пекина министру иностранных дел А. П. Извольскому: «Пренебрегая историческими примерами и мнением многочисленной духовной паствы Далай-ламы, китайское правительство отнеслось к нему как к обыкновенному вассалу, приехавшему для поклонения своему сюзерену - и с этой узко-политической точки зрения сообразовало все подробности приема Первосвященника. Умалить престиж Далай-ламы, лишить его в глазах верных ему ламаитов прежнего его обаяния, указать ему на истинное его место- как духовного лишь пастыря, лишенного волею Богдохана светской власти - вот намерения китайского правительства, сказавшиеся с первых же дней по приезде сюда Его Святейшества» [АВПРИ. Ф. МП. ОП. 761. Д. 410. Л. 221].

Аудиенция была перенесена в связи с тем, что Далай-лама не соглашался на унизительный церемониал. «После долгих колебаний Первосвященник, чувствуя свое бессилие в китайской столице, окруженный китайскими придворными, вынужден был согласиться - и церемониал аудиенции состоялся, как того хотели китайские власти» [АВПРИ. Ф. МП. Оп. 761. Д. 410. Л. 221].

Такому же унизительному церемониалу ему пришлось подвергнуться и на придворном пиршестве в его честь 17 октября. То же повторилось и при поздравлении вдовствующей императрицы с днем рождения. Кроме того, китайские сановники грубо обращались с ним, стараясь доказать полную от них зависимость. В этих условиях Далай-лама старался покинуть Пекин как можно ско- pee. Попытки окружавших его хамбо-лам получить частным образом справку в Лифаньюане относительно планов реформирования в Тибете не увенчались успехом. На все просьбы первосвященника о воздействии И. Я. Коростовца на китайское правительство тот отвечал, что это невозможно, так как было бы нарушением соглашения России с Англией и вызвало бы «справедливые протесты Китая» против вторжения в сферу его «сюзеренных прав» [АВПРИ. Ф. МП. Оп. 761. Д. 410. Л. 221]. При разговоре с И. Я. Коростовцом английский посланник сказал, что, «решительно не признавая за главой ламаизма права на светскую власть, он не намерен вступать с ним в какие бы то ни было сношения по политическому движению Тибета, всецело составляющего владения китайского правительства» [АВПРИ. Ф. МП. Оп. 761. Д. 410. Л. 221].

Этой ситуацией Далай-лама был обязан, прежде всего, самому И. Я. Коростовцу, английскому посланнику и действовавшему с ведома японского посольства Э. Терамото, понуждавших его выполнить ритуал следования «китайскому сюзеренитету», декларированному для Тибета иностранными державами. Однако из приведенных донесений И. Я. Коростовца (который был не на всех аудиенциях) не следует, что Далай-лама каждый раз совершал коутоу. На первой и официальной аудиенции -1 октября (очевидно, 14 октября по новому стилю) поклоны были проще. Это согласуется и с китайскими данными: после возражений Далай-ламы был найден компромисс вместо традиционного простирания лишь коленопреклонение (преклонить правое колено и коснуться правой рукой земли) [Rockhill 1910: 78-79].

В. В. Смит отмечает, что коутоу было совершено не на официальной церемонии, а на личной, которая не имела политического значения [Smith 1996: 166].

Смерть Цыси и отравленного ею императора Гуансюя Далай-лама застал в Пекине. Он неоднократно спрашивал И. Я. Коростовца, как ему выразить свое соболезнование князю-регенту и императорской семье. Совет он получил в прежнем стиле: «Я посоветовал ему просить через министерство колоний разрешить соборне с ламаистским духовенством обряд поклонения перед гробами их величеств. Далай-лама это испол- 
нил. Немедленно же был издан указ, что обряд поклонения состоялся 7 ноября. Соболезнования, выраженные Далай-ламой в этой форме, произвели очень хорошее впечатление на князя Регента и, по имеющимся сведениям, центральное правительство намеревается пожаловать ему новых 4 эпитета при торжестве восшествия на престол, имеющем состояться 1 января будущего года $<\ldots>$ Соболезнуя о малом успехе Далай-ламы в Пекине, Агван Доржиев довольно открыто приписывал этот неуспех слишком упрямому характеру Первосвященника, чрезвычайной гордости его и нежеланию сблизиться с прикомандированными к нему членами министерств колоний и иностранных дел» [АВПРИ. Ф. МП. Оп. 761. Д. 410. Л. 2-5]. Итак, новые поклоны были сделаны тоже не без советов И. Я. Коростовца. Это было 7 ноября 1908 г., когда Далай-лама с 88 учениками читал религиозные книги по поводу кончины императора («Шуньтянь шибао»: [АВПРИ. Ф. МП. Оп. 761. Д. 410. Л. 240]).

Смерть Гуансюя и Цыси не дала возможности совершить церемонию «возведения в сан», присвоенный Далай-ламе цитированным выше указом и, в частности, получить титул «Искренне послушный и помогающий просвещению» («Шуньтянь шибао», 08.11.1908: [АВПРИ. Ф. МП. Оп. 761. Д. 410. Л. 241]). Более того: ввиду сложной обстановки нельзя было предвидеть, «какую форму примут отношения Далай-ламы с новым китайским правительством» (письмо А. П. Извольского из Петербурга от 11 ноября 1908 г. министру финансов: [АВПРИ. Ф. МП. Оп. 761. Д. 410. Л. 242]).

Лишь 16 декабря 1908 г. состоялся доклад министерства церемоний о вручении Далай-ламе грамоты на пожалование ему титула с приложением описания церемониала этого пожалования. Предлагалось переслать грамоту амбаню в г. Синин, чтобы он отправился к Далай-ламе и вручил ему. Церемониал вручения был вынесен на Высочайшее рассмотрение и утвержден императорским указом от 11 декабря 1908 г. В Синине грамоту следовало поставить в главной зале, правитель Синина должен был заранее оповестить Далай-ламу, совершить перед грамотой коленопреклонение с 3 поклонами. После длительной церемонии, согласно предложенному церемониалу, должны были ввести Далай-ламу, он должен был совершить 3 коленопреклонения с 9 земными поклонами. Затем должен был последовать церемониал вручения грамоты, после которого Далай-лама должен был подойти к столу с грамотой и совершить 3 коленопреклонения с 9 земными поклонами [АВПРИ. Ф. МП. Оп. 761. Д. 410. Л. 300об.-301]. Неизвестно, было ли все это выполнено. Согласно докладу сининского амбаня Цинь Шу, грамоту отправили 19 февраля для вручения Далай-ламе. 23 марта 1909 г. он вручил ее в Тарсы. Там Далай-лама принял грамоту, поблагодарив императора с радостью. О коленопреклонениях не сообщалось [АВПРИ. Ф. МП. Оп. 761. Д. 410. Л. 346-348].

Анализ титулов, которыми подписывался Далай-лама в разное время, показал, что цинские новации о его «покорности» и пр. Далай-лама не счел для себя обязательными. Эта часть в тибетском переводе нового титула в 1909 г. была просто транслитерирована тибетскими буквами с китайских иероглифов [Ishihama et al. 2019: 89-91].

8 декабря 1909 г. Далай-лама вернулся в Лхасу после 5-летнего отсутствия. Он выпустил новые серебряные монеты с названием тибетского правительства - Ганден Пходранг, в составе которого создал МИД. Отрицая последнюю пекинскую модификацию титула Далай-ламы, тибетцы вручили ему новую печать с надписью: «По пророчеству повелителя Будды, Далай-лама, держатель буддийской веры на лице этой земли» [Dhondup 1986: 21-22]. Так Далай-лама больше не использовал фразеологию, указывающую, что он обязан своим утверждением императору. Теперь его титулатура гласила: «Речь того, кто назван самым могущественным повелителем в высшей степени добродетельной западной сферы, держателем всего учения Будды на земле, всеведущим Ваджрадхарой Далай-ламой» [Schwieger 2015: 208]. Вряд ли Далай-лама стал бы так поступать, если бы он считал свои коленопреклонения и принятие императорской грамоты признаками подчинения Тибета Пекину.

12 февраля 1910 г. в Лхасу вступили цинские войска, что сопровождалось бесчинствами. В ночь на 13 февраля Далай-лама отбыл в Индию. Тибетцы говорили Ч. Беллу, знакомому с Далай-ламой, что 
если бы он не бежал в Индию, то китайцы заключили бы его в тюрьму, этим разрушив независимость Тибета [Bell 1946: 89].

$12\left(25^{8}\right)$ февраля 1910 г. от имени малолетнего цинского императора Пуи был издан абсурдный указ о «низложении» Далай-ламы. Как сообщал И. Я. Коростовец из Пекина 24 февраля (9 марта) 1910 г., это низложение произведет плохое впечатление на буддистов Тибета и Монголии [АВПРИ. Ф. КС. Оп. 491. Д. 1458. Л. 59-59об.]. Новый указ был еще одним шагом к превращению Тибета в цинскую провинцию. Теперь Пекин объявил вассалами Непал и Бутан, а на Тибет предъявил суверенные права: якобы стадия сюзеренитета уже прошла [Bell 1924: 114]. «Обратив вассальный Тибет в китайскую провинцию, он одним искусным шагом уничтожил буфер, доселе существовавший между Индией и Китаем» (депеша консула Б. К. Арсеньева из Калькутты в МИД от 18 марта 1910 г.: [АВПРИ. Ф. КС. Оп. 491. Д. 1458. Л. 81об.]).

Указ о «разжаловании» Далай-ламы встретил возражения Великобритании. Как писала «Чжунго бао» 16.02.1910, «со времени опубликования указа о свержении Далай-ламы иностранцы одного государства в высшей степени неспокойны и неоднократно уже ставили на вид китайскому правительству, что Тибет находится лишь под протекторатом Китая, а потому предпринятая там ныне политика является в высшей степени не согласующейся с постановлениями международного права» (рус. перев.: [АВПРИ. Ф. МП. Оп. 761. Д. 411. Л. 68]). Некоторые тибетцы тоже считали свою страну «под протекторатом Китая» [АВПРИ. Ф. МП. Оп. 761. Д. 411. Л. 67-68].

14 марта 1910 г. Далай-лама посетил правительственную резиденцию в Калькутте и обратился к вице-королю лорду Г. Э.-М.-К. Минто с просьбой о помощи в выводе китайских войск. Он выразил желание достигнуть положения Далай-ламы V, который был независимым сувереном, а также отказался признавать соглашения Англии с Пекином, заключенные без участия Тибета. Он отметил, что не верит больше письменным «заверениям китайского правительства» после того, как китайцы

8 Здесь и далее в скобках даны даты по григорианскому календарю (по новому стилю). полностью нарушили обещания, данные ему вдовствующей императрицей [Bell 1946: 94; Dhondup 1986: 24].

Далай-лама в своих письмах просил монархов Великобритании, России и Японии о поддержке независимости Тибета, сообщал, что отношения с Китаем основывались лишь на отношениях «наставник - покровитель» между Далай-ламой и маньчжурским императором [Россия и Тибет 2005: 195; From Tibet 2011: 73; Kobayashi 2016: 288-308; Kobayashi 2018: 117]. То же подразумевал он и в письме, которое написал цинскому императору и его посланнику Ло Титаю, приехавшему к нему для переговоров в Дарджилинг: «Легально, Китай и Тибет продолжают иметь разных лидеров» [Shakabpa 2010: 731]. В переводе письма о причинах бегства Далай-ламы, привезенного Ф. И. Щербатским из Индии, подчеркивалось: «Искони Тибет представлял собою государство» [АВПРИ. Ф. КС. Оп. 491. Д. 1458. Л. 205-212].

11 января 1913 г. с санкции теократических монархов Богдо-гэгэна VIII и Далай-ламы XIII был подписан Монголо-тибетский договор, где Монголия и Тибет признавали друг друга независимыми государствами. Этот договор действителен с международно-правовой точки зрения, так как независимая Монголия заключила его, будучи уже формально признана Россией [Кузьмин 2014: 155-157].

23 января 1913 г. Далай-лама XIII вернулся в Лхасу. Вскоре он послал письмо в Англию, где писал: «Китай и Тибет в течение долгого времени находились лишь в отношениях „наставник - покровитель“. Я уже писал о том, что Тибет никогда не контролировался Китаем» [Kobayashi 2014: 95].

Вскоре он издал декларацию независимости (перевод: [Шакабпа 2003: 260-262]). В ней, в частности, говорилось, что отношения между Тибетом и Китаем никогда не строились на подчинении одной страны другой, прежние отношения прекратились, а сейчас надо сохранять и поддерживать независимость Тибета.

Далай-лама призывал державы помочь Тибету. Так, он писал министру иностранных дел России 22 апреля 1913 г., что не желает быть подданным Китая, что Тибет должен обладать «самоуправлением неза- 
висимо от Китая», и просил Россию помочь в этом и в прекращении китайской интервенции [АВПРИ. Ф. КС. Оп. 491. Д. 1458. Л. 354].

В интервью «Новому времени» за 25 января (07 февраля) 1913 г. А. Доржиев отмечал, что «после провозглашения независимости Далай-лама стал „тусхай“, то есть отдельным государем, повелителем, избранным народом» [АВПРИ. Ф. МП. Оп. 761. Д. 376. Л. 37].

Через несколько месяцев после своего возвращения Далай-лама получил телеграмму президента Китая Юань Шикая с извинениями за эксцессы и «восстановлением» его в прежнем ранге. Далай-лама ответил, что не просил никакого ранга, так как сам намерен осуществлять светскую и духовную власть в Тибете. Так он разъяснил свою декларацию независимости [Bell 1946: 135].

Далай-лама говорил Ч. Беллу: «Я хотел бы, чтобы Тибет был полностью независимым от Китая», и приводил такие аргументы: «Связь с Китаем - это была связь Далай-ламы с маньчжурским императором. Маньчжуры считались буддистами, китайцы - нет. Когда вспыхнула китайская революция в 1911 г., китайцы низложили маньчжурского императора. С тех пор между ними двумя больше не было связи. Связующее звено было разбито, и теперь Тибет полностью отделен от Китая» [Bell 1946: 356-357]. Надо отметить, что такие же аргументы о независимости Монголии приводил и ее теократический монарх - Богдо-гэгэн Джебцзундамба-хутухта VIII.

Возможность признания нового статуса Тибета открылась переговорами, начавшимися в Симле в 1913 г. Представитель Великобритании Г. Макмагон предложил разделить Тибет на две зоны: «Внешний Тибет» и «Внутренний Тибет» (по примеру Монголии, по которой вскоре - в 1915 г. - было подписано соглашение между Китаем, Россией и Внешней Монголией, признававшее последнюю автономией под сюзеренитетом Китая). Теперь же указывался сюзеренитет Китая над Тибетом, и для «Внешнего Тибета» признавалась автономия. Китай отказался подписать это соглашение, но 3 июля 1914 г. была подписана двусторонняя англо-тибетская декларация, где говорилось о том, что по- следняя обязательна для Великобритании и Тибета, но Китай сможет пользоваться вытекающими из нее привилегиями, только подписав ee [VanWalt 1987: 58]. Важно отметить, что в тибетском тексте конвенции слово «автономия» передано словом рангизен [Ishihama et al. 2019: 140] - независимость. Среди печатей на декларации была и печать Далай-ламы. Китайская республика, так и не подписав симласкую конвенцию, лишилась возможности ссылаться на нее как на документ, подтверждающий ее сюзеренитет над Тибетом, а последний признал такой сюзеренитет (при собственной независимости в тибетском тексте) только «в одном пакете» с признанием линии Макмагона, не признанной Китаем. Но сам Китай не принял это признание, и статус Тибета не изменился.

\section{Заключение}

Далай-лама XIII использовал термин гья-наг, который традиционно относился к режимам, контролировавшим территории ханьцев, как Мин, Цин и Китайская республика. Это слово не имело китайского значения Чжунго - «Срединное государство», которое подразумевает «центр» и «периферию» [Kobayashi 2014: 95]. Иными словами, в нем не отражено какое-либо превосходство Китая или империй со столицей в Пекине.

То, что в Пекине трактовали как реальное управление тибетскими делами, можно трактовать лишь как помощь в них, а не осуществление властных функций (детальный разбор цинских документов о Тибете см.: [A 60-point Commentary... 2008]). Эти контакты адекватно описываются отношениями «наставник - покровитель», что соответствует высказываниям Далай-ламы XIII. Официальные и неофициальные цинские трактовки положения Тибета как подчиненного или включенного в империю являлись односторонними и не отражающими реальность. Важно учитывать крайнюю недостоверность цинских материалов об отношениях империи Цин с соседями [Тихвинский 1966: 25].

Отношения империи Цин и Тибета стали меняться в начале XX в. в рамках цинской «новой политики», связанной с экспансией европейцев и японцев: Пекин решил заселить «периферию» китайцами (ханьцами), 
проводить китаизацию Монголии и Тибета, разработку их природных богатств, введение войск и т. д. Преимущественно к этому времени и относится постепенный переход в вассальную зависимость Тибета от Китая, о котором говорил Далай-лама (см. выше). Это было нарушением отношений «наставник - покровитель». И не только их, но и системы высшей власти в империи: в ней правила вдовствующая императрица вместо законного императора.

Россия и Великобритания не знали о несводимости отношений империи Цин с Тибетом к таковым в европейском мире. Для своего удобства они юридически зафиксировали «китайский сюзеренитет» над Тибетом. Это был европейский конструкт, основанный на «пересадке» феодальной терминологии государств Европы и Передней Азии, лучше знакомых европейским дипломатам.

\section{Источники}

АВПРИ - Архив внешней политики Российской империи. Ф. КС - Фонд «Китайский стол»; Ф. МП - Фонд «Миссия в Пекине».

\section{Литература}

Белов 1996 - Белов Е. А. Записка подполковника Генерального штаба Хитрово о Далай-ламе и его деятельности 1906 года // Восток (Oriens). 1996. № 4. C. 136-141.

Беспрозванных 2001 - Беспрозванных Е. Л. Лидеры Тибета и их роль в тибето-китайских отношениях XVII-XVIII в. Волгоград: ВГУ. $2001.356 \mathrm{c}$.

Дмитриев, Кузьмин 2012 - Дмитриев С. В., Кузьмин С. Л. Что такое Китай? Срединное государство в историческом мифе и реальной политике // Восток (Oriens). 2012. № 3. С. 5-19.

Дмитриев, Кузьмин 2014 - Дмитриев С. В., Кузьмин С. Л. Империя Цин как Китай: анатомия исторического мифа // Восток (Oriens). 2014. № 1. C. 5-17.

Кузьмин $2010-$ Кузьмин С. Л. Скрытый Тибет. История независимости и оккупации. СПб.: Изд-во А. Терентьева, 2010. 544 с.

Кузьмин $2012-$ Кузьмин С. Л. Отношения «наставник - покровитель» и проблема статуса Тибета // Наука и буддизм. Улан-Удэ: Издво Бурят. гос. ун-та, 2012. С. 261-273.
Далай-лама XIII, не имея внешней поддержки и рассчитывая на Россию, а затем и Великобританию, вынужден был принять это - но на короткое время и в своеобразной форме, не отказываясь от тибетской государственности. По настоянию иностранцев совершив ритуал поклонения перед троном и приняв императорскую грамоту, Далай-лама по возвращении в Тибет продемонстрировал, что он считал это лишь формальностью. Его бегство в Индию и новые просьбы к державам о помощи независимости Тибета показывают, что тибето-цинские отношения обеими сторонами трактовались по-разному. Следовательно, Далай-лама так и не стал вассалом императора, а Тибет - частью империи Цин. Коллапс этой империи и отречение маньчжурской династии от престола дали новое основание Далай-ламе заявлять о независимости Тибета.

Кузьмин $2014-$ Кузьмин С. Л. Государственность Тибета // Государственность народов Внутренней Азии. Прага: Sociosféra-CZ, 2014. C. 140-161.

Кузьмин 2019 - Кузьмин С. Л. Вассалитет на Западе и Востоке: проблема отношений империи Цин с Монголией и Тибетом // Восток (Oriens). 2019. № 1. С. 39-54.

Россия и Тибет 2005 - Россия и Тибет. Сб. рус. арх. док-тов. 1900-1914. М.: Вост. лит., 2005. $231 \mathrm{c}$.

Сабрукова 2015 - Сабрукова С. С. Послание Далай-ламы XIII к тибетскому народу. Документ из фонда Д. А. Клеменца (по материалам Архива востоковедов ИВР РАН) // Учение Будды в России: 250 лет институту Пандито Хамбо-лам. СПб.: Петербургское востоковедение, 2015. С. 134-139.

Тихвинский 1966 - Тихвинский С. Л. Маньчжурское владычество в Китае // Маньчжурское владычество в Китае. М.: Наука, 1966. C. 5-76.

Уложение 1828 - Уложение китайской Палаты внешних сношений : в 2 т. СПб.: Тип. Департамента народ. просвещения, 1828. Т. 1. 326 c. Т. 2.319 c.

Шакабпа 2003 - Шакабпа В. Д. Тибет: политическая история. СПб.: Нартанг, 2003. 428 с.

A 60-point commentary ... 2008 - A 60-point commentary on the Chinese Government Publication. Dharamsala: DIIR, 2008. 185 p. 
Backhouse, Bland 1914 - Backhouse E., Bland J. O. P. Annals and Memoirs of the Court of Peking (from the $16^{\text {th }}$ to the $20^{\text {th }}$ Century). London: W. Heinemann, 1914. 531 p.

Bell 1924 - Bell Ch. Tibet: Past and Present. Oxford: Clarendon Press, 1924. 326 p.

Bell 1928 - Bell Ch. The People of Tibet. Oxford: Clarendon Press, 1928. 319 p.

Bell 1946 - Bell Ch. Portrait of the Dalai Lama. London: Collins, 1946. 414 p.

Cheney 2017 - Cheney A. J. Tibet lost in translation: sovereignty, suzerainty and international order transformation, 1904-1906 // Journal of Contemporary China. 2017. Vol. 26, no 107. Pp. 1-15.

Dhondup1986 - Dhondup K. The Water-Bird and Other Years. A History of the $20^{\text {th }}$ Dalai Lama and After. New Delhi: Rang Wang, 1986. 125 p.

Fairbank, Teng 1941 - Fairbank J. K., Teng S. Y. On the Ch'ing tributary system // Harvard Journal of Asiatic Studies. 1941. Vol. 6, no. 2. Pp. 135-246.

From Tibet 2011 - From Tibet Confidentially. Secret correspondence of the Thirteenth Dalai Lama to Agvan Dorzhiev, 1911-1925. Dharamsala: LTWA, 2011. 192 p.

Ishihama et al. 2019 - Ishihama Y., Tachibana M., Kobayashi R., Inoue T. The Resurgence of «Buddhist Government».Tibetan-Mongolian Relations in the Modern World. Osaka: Union Press, 2019. 292 p.

\section{Sources}

Archive of Foreign Policy of the Russian Empire. Coll. 'Chinese Table (Department)'; coll. 'Mission in Beijing'. (In Russ.)

\section{References}

[Chinese Chamber of External Relations: Code of Laws]. In 2 vols. St. Petersburg: Public Education Dept., 1828. Vol. 1, 326 p.; vol. 2, 319 p. (In Russ.)

[Russia and Tibet: Collected Archival Documents, 1900-1914]. Moscow: Vostochnaya Literatura, 2005. 231 p. (In Russ.)

A 60-point commentary on the Chinese Government Publication. Dharamsala: DIIR, 2008. 185 p. (In Eng.)

Backhouse E., Bland J. O. P. Annals and Memoirs of the Court of Peking (from the $16^{\text {th }}$ to the $20^{\text {th }}$ Century). London: W. Heinemann, 1914. 531 p. (In Eng.)
Kobayashi 2014 - Kobayashi R. Tibet in the era of 1911 Revolution // Journal of Contemporary China Studies. 2014. Vol. 3. No. 1. Pp. 91-113.

Kobayashi 2016 - Kobayashi R. The Lungshar delegation and Britain in 1913. Focusing on the letters of the $13^{\text {th }}$ Dalai Lama // Inner Asia. 2016. Vol. 18. Pp. 288-308.

Kobayashi 2018 - Kobayashi $R$. The Tibet-Japan relations in the era of the 1911 revolution. Tibetan letters from the Aoki Bunkyō Archive // Chibetto Himaraya bunmei no rekishiteki tenkai. Kyoto: Kyoto University, 2018. Pp. 101-22.

Rockhill 1910 - Rockhill W. W. The Dalai Lamas of Lhasa and Their Relations with the Manchu Emperors of China. 1644-1908 // T'oung Pao. $2^{\text {nd }}$ Ser. 1910. Vol. 11, No. 1. Pp. 1-104.

Schwieger 2015 - Schwieger P. The Dalai Lama and the Emperor of China. A Political History of the Tibetan Institution of Reincarnation. New York: Columbia University Press, 2015. 557 p. Shakabpa 2010 - Shakabpa W. D. One Hundred Thousand Moons: an Advanced Political History of Tibet. Vol. 2. Leiden: Brill, 2010. $1184 \mathrm{p}$.

Smith 1996 - Smith $W . \quad W$. Tibetan Nation. Boulder: Westview Press, 1996. 732 p.

Van Walt 1987 - Van Walt van Praag M. C. The Status of Tibet: History, Rights, and Prospects in International Law. Boulder: Westview Press, 1987. $381 \mathrm{p}$.

Bell Ch. Portrait of the Dalai Lama. London: Collins, 1946. 414 p. (In Eng.)

Bell Ch. The People of Tibet. Oxford: Clarendon Press, 1928. 319 p. (In Eng.)

Bell Ch. Tibet: Past and Present. Oxford: Clarendon Press, 1924. 326 p. (In Eng.)

Belov E. V. Lieutenant colonel Khitrovo's report on the Dalai Lama and his activity in 1906. Oriens. 1996. No. 4. Pp. 136-141. (In Russ.)

Besprozvannykh E. L. [Leaders of Tibet and Their Role in Tibet - China Relations: $17^{\text {th }}-18^{\text {th }}$ Centuries]. Volgograd: Volgograd State University, 2001. 356 p. (In Russ.)

Cheney A. J. Tibet lost in translation: sovereignty, suzerainty and international order transformation, 1904-1906. Journal of Contemporary China. 2017. Vol. 26. No 107. Pp. 1-15. (In Eng.)

Dhondup K. The Water-Bird and Other Years. A History of the $20^{\text {th }}$ Dalai Lama and After. New Delhi: Rang Wang, 1986. 125 p. (In Eng.) 
Dmitriev S. V., Kuzmin S. L. Qing Empire as China: anatomy of historical myth. Oriens. 2014 No. 1. Pp. 5-17. (In Russ.)

Dmitriev S. V., Kuzmin S. L. What is China? Middle State in historical myth and real policy. Oriens. 2012. No. 3. Pp. 5-19. (In Russ.)

Fairbank J. K., Teng S. Y. On the Ch'ing tributary system. Harvard Journal of Asiatic Studies. 1941. Vol. 6. No. 2. Pp. 135-246. (In Eng.)

From Tibet Confidentially. Secret correspondence of the Thirteenth Dalai Lama to Agvan Dorzhiev, 1911-1925. Dharamsala: LTWA, 2011. 192 p. (In Eng.)

Ishihama Y., Tachibana M., Kobayashi R., Inoue T. The Resurgence of 'Buddhist Government'. Tibetan-Mongolian Relations in the Modern World. Osaka: Union Press, 2019. 292 p. (In Eng.)

Kobayashi R. The Lungshar delegation and Britain in 1913. Focusing on the letters of the $13^{\text {th }}$ Dalai Lama. Inner Asia. 2016. Vol. 18. Pp. 288-308. (In Eng.)

Kobayashi R. The Tibet-Japan relations in the era of the 1911 revolution. Tibetan letters from the Aoki Bunkyō Archive. In: [The Historical Development of Tibeto-Himalayan Civilization]. Kyoto: Kyoto University, 2018. Pp. 101-22. (In Eng.)

Kobayashi R. Tibet in the era of 1911 Revolution. Journal of Contemporary China Studies. 2014. Vol. 3. No. 1. Pp. 91-113. (In Eng.)

Kuzmin S. L. 'Priest-patron' relationships and status of Tibet. In: [Science and Buddhism]. UlanUde: Buryat State University, 2012. Pp. 261273. (In Russ.)
Kuzmin S. L. Statehood of Tibet. In: [Peoples of Inner Asia: Issues of Statehood]. Prague: Sociosféra-CZ, 2014. Pp. 140-161. (In Russ.)

Kuzmin S. L. The problem of vassalage in the West and the East: relations of the Qing Empire with Mongolia and Tibet. Oriens. 2019. No. 1. Pp. 39-54. (In Russ.)

Kuzmin S. L. [Hidden Tibet]. St. Petersburg: A. Terentiev, 2010. 544 p. (In Russ.)

Rockhill W. W. The Dalai Lamas of Lhasa and their relations with the Manchu Emperors of China. 1644-1908. T'oung Pao. $2^{\text {nd }}$ Ser. 1910. Vol. 11. No. 1. Pp. 1-104. (In Eng.)

Sabrukova S. S. Letter of the $13^{\text {th }}$ Dalai Lama to the Tibetan people. In: [Buddha's Teaching in Russia]. St. Petersburg: Peterburgskoe Vostokovedenie, 2015. Pp. 134-139. (In Russ.)

Schwieger P. The Dalai Lama and the Emperor of China. A Political History of the Tibetan Institution of Reincarnation. New York: Columbia University Press, 2015. 557 p. (In Eng.)

Shakabpa W. D. One Hundred Thousand Moons: an Advanced Political History of Tibet. Vol. 2. Leiden: Brill, 2010. 1184 p. (In Eng.)

Shakabpa W. D. Tibet: a Political History. St. Petersburg: Narthang, 2003, 428 p. (In Russ.)

Smith W. W. Tibetan Nation. Boulder: Westview Press, 1996. 732 p. (In Eng.)

Tikhvinsky S. L. Manchu rule in China. In: [Manchu Rule in China]. Moscow: Nauka, 1966. Pp. 5-76. (In Russ.)

Van Walt van Praag M. C. The Status of Tibet: History, Rights, and Prospects in International Law. Boulder: Westview Press, 1987. 381 p. (In Eng.) 